\title{
MODEL DESA BINAAN (TAHUN II) PEMBINAAN TEKNIS BUDIDAYA KAMBING KACANG DI DESA KEMIRI, TANJUNGSARI, GUNUNG KIDUL, YOGYAKARTA
}

\section{Assisted Village Model (Year II) Technical Development of Kacang Goat Cultivation in Kemiri Village, Tanjungsari, Gunung Kidul, Yogyakarta}

\author{
Sarmin, Amelia Hana, Pudji Astuti, Yuda Heru Fibrianto, Claude Mona Airin \\ Departemen Fisiologi Fakultas Kedokteran Hewan Universitas Gadjah Mada \\ Jl Fauna 2 Karangmalang, Yogyakarta
}

\begin{abstract}
Article history
Received: Aug 11, 2021;

Accepted: Nov 07, 2021

* Corresponding author:

E-mail:

sarminkh76@ugm.ac.id

DOI: https://doi.org/10.465

49/igkojei.v2i3.254

ABSTRACT

This 2 nd year assisted village activity is a part of the 3 years assisted village which aims to make Kemiri an Integrated Farming Area. This year's stage focuses on efforts to improve goat farming skills in the Kemiri community, Tanjungsari sub-district, Gunungkidul Regency. The activity was carried out by initiating the breeding of Kacang goats and offering consultation. Further assistance is needed to further increase the capacity of farmers and support the economic independence of farmers through goat farming in the form of marketing, postproduction technology, and the processing offeed and waste.

Keywords: Assisted village; Kacang goats; Kemiri.

\section{ABSTRAK}

Kegiatan desa binaan tahun ke-2 ini sebagai bagian dari desa binaan 3 tahun yang bertujuan menjadikan Kemiri Sebagai Kawasan Petenakan Terpadu. Tahapan tahun ni menitikberatakan pada upaya peningkatan keterampilan budidaya kambing pada masyarakat Kemiri, kecamatan Tanjungsari, Kabupaten Gunungkidul. Kegiatan dilakukan dengan inisiasi budidaya kambing kacang dan konsultatif. Pendampingan lanjutan diperlukan untuk semakin meingkatkan kapasitas peternak dan menyangga kemandirian ekonomi peternak melalui budi daya kambing berupa pemasaran, teknologi pasca produksi, pengolahan pakan dan limbah.

Kata kunci: desa binaan; Kambing kacang; Kemiri.

\section{PENDAHULUAN}

Kemiri adalah desa di kecamatan Tanjungsari, Gunungkidul, Daerah Istimewa Yogyakarta, Desa Kemiri memiliki 11 Padukuhan yang terdiri dari Glagah, Kemiri, Bareng, Ngasem, Panggang, Wates, Guyangan, Karangnongko, Dayakan 1 dan Dayakan 2. Budidaya peternakan merupakan keahlian turun menurun sehingga praktek beternak masih sangat tradisional.

Mulai tahun 2019 dimulai kegiaan desa binaan tahun I dengan kegiatan berupa praktik fermentasi pakan menggunalan bahan pakan lokal bersinergi dengan kuliah kerja nyata pembelajaran pemberdayaan masyarakat Universitas Gadjah Mada (KKN PPM UGM Unit YO-120), dimulai dari balai desa kemudian dilanjutkan pada Padakuhan Wates, Ngasem, Panggang, dan Gebang. Hasil
\end{abstract}


kegiatan desa binaan tahun I menjadikan peternak memiliki kemampuan dalam mengolah bahan alam yang ada di desa Kemiri sebagai pakan ternak. Teknologi fermentasi merupakan metode dalam pemanfatan bahan pakal lokal (Pamungkas, 2011). Setelah kemampuan warga desa binaan dalam penyediaan pakan meningkat, tahun tahun II mulai diperkenalkan budi daya kambing. Kegiatan desa binaan tahun ke-2 ini sebagai bagian dari desa binaan 3 tahun yang bertujuan menjadikan Kemiri Sebagai Kawasan Petenakan Terpadu. Tahapan tahun II ni menitikberatakan pada upaya peningkatan keterampilan budi daya kambing pada masyarakat Kemiri, kecamatan Tanjungsari, Kabupaten Gunungkidul. Kambing kacang dimunculkan sebagai unggulan daerah Istimewa Yogyakarta (Kusumastuti, 2012), meskipun Gunungkidul adalah asal mula kambing bligon (Murdjito et al., 2011). Kambing kacang berptensi dikembangkan di desa Kemiri yang beriklim kering demikian juga budi daya kambing kacang dapat mengembalikan atau melebihi social opportunity cost faktor produksi modal yang dipergunakan (Kusumastuti, 2012), dan memiliki daya tahan yang tinggi pada keadaan pakan terbatas (Sarmin et al., 2017). Oleh karena itu tujuan kegiatan ini adalah menginisiasi budi daya kambing kacang di desa Kemiri, KecamatanTanjungsari, Kabupaten Gunungkidul.

\section{METODE}

Kegiatan dilakukan melalui tahapan pembinaan teknis manajemen budidaya kambing meliputi pakan, kandang, kesehatan, manjemen reproduksi dan pengolaham limbah secara daring dikarenakan situasi pandemi. Kegiatan selanjutnya adalah menstimulasi bibit kambing kacang pada kelompok masyarakat.

\section{HASIL DAN PEMBAHASAN}

Tahun 2019, Desa Kemiri, KecamatanTanjungsari, Kabupaten Gunungkidul dicananhkan sebagai desa mandiri pangan (Grehenson, 2016). Langkah tahun I dilakukan dengan kegiatan berupa praktik fermentasi pakan menggunalan bahan pakan lokal untuk memenuhi kebutuhan pakan ternak. Realisasi tahun II dengan menstimulasi bibit kambing kacang sebagai bagian upaya tindaklanjut bagi peternak setelah memiliki keterampilan mengolah pakan pada tahun I. Kambing kacang dipilih karena kambing kacang dapat tumbuh pada daerah yang ketersediaan pakan tidak melimpah karena kebutuhan energi lebih sedikit dengan postur tubuh yang kecil (Kusumastuti, 2012) dan berbukitbukit (Gambar 1). Kambing lain yang berhasil dikembangkan di Gunungkidul antara lain bligon (Murdjito et al., 2012) dan (Widi et al., 2016) di Girisekar, panggang, Gunungkidul, dan daerah Gombong, Ponjong, Gunungkidul (Kawuriaji et al., 2012). 


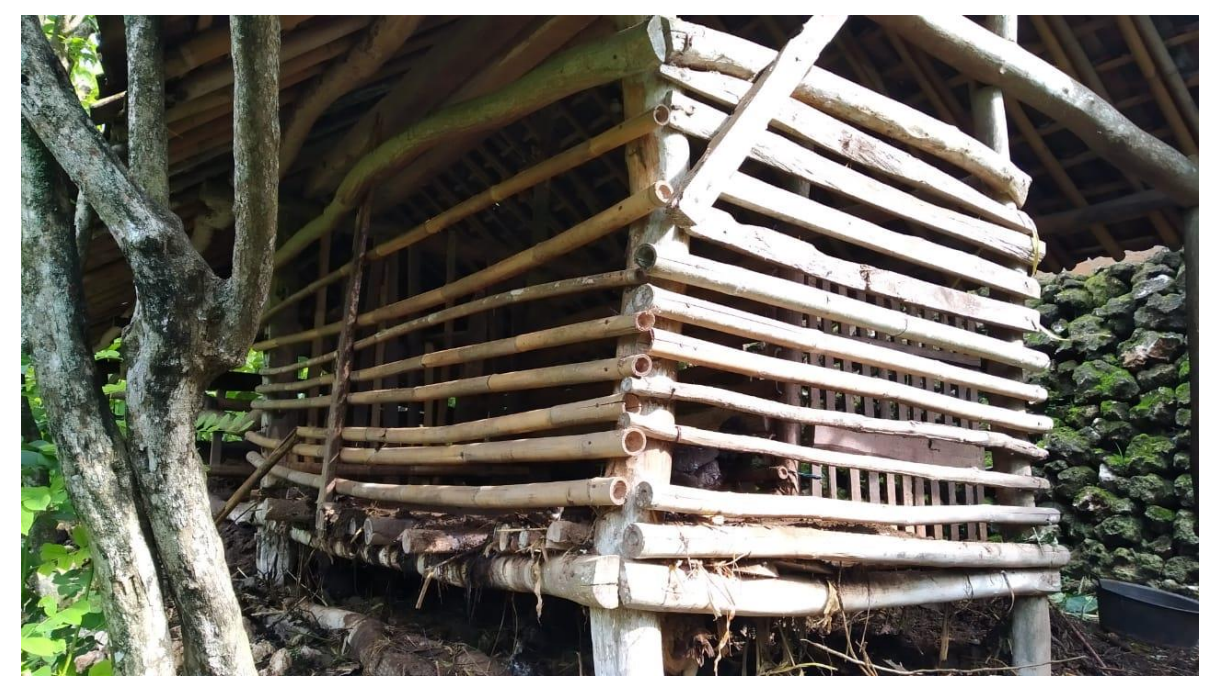

Gambar 1. Posisi kandang kambing diantara bukit -bukit

Kambing kacang juga merupakan kambing lokal yang mudah beradaptasi dengan potensi pakan lokal (Kustantinah et al., 2016), reproduksinya cukup bagus pada kondisi pakan yang kurang (Suwignyo et al., 2017; Widiyono et al., 2016; Sarmin et al., 2017) dan warga sudah terbiasa membudidayakan kambing kacang.

Hasil budidaya kambing kacang menunjukkan bahwa kambig kacang mampu beradaptasi dengan baik di desa Kemiri dengan ditunjukkan body score condition pada level 4 (Villaquiran et al., 1977) (Gambar 2) demikian juga sebagian diantara bibit kambing telah mulai bunting.

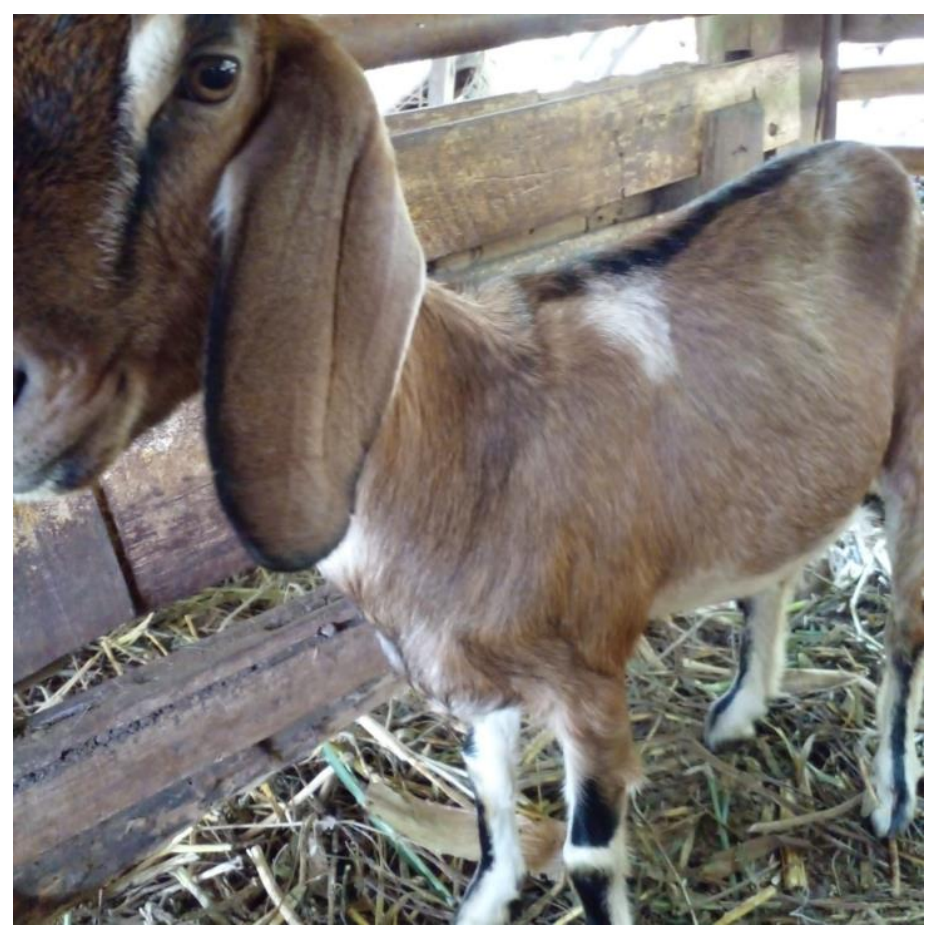

Gambar 2. Kambing kacang telah beradaptasi di desa Kemiri, nampak body condition score 4 pada kambing yang dibudidayakan 


\section{KESIMPULAN}

Desa Binaan dengan kegiatan mengisiasi budidaya kambing kacang pada masyarakat desa Kemiri, kecamatan Tanjungsari, Kabupaten Gunungkidul melalui kegiatan desa binaan dapat berhasil dengan indikator pertmbuhan kambing yang pada body condition score rata-rata 4 dan sebagian kambing telah mulai bunting.

\section{UCAPAN TERIMA KASIH}

Ucapan terima kasih disampaikan kepada Dekan Fakultas Kedokteran Hewan Universitas Gadjah Mada atas dukungan pendanaan kegiatan ini dengan nomor kontrak: 1383/UN1/FKH/HK4/2020 tanggal 12 Mei 2020.

\section{DAFTAR PUSTAKA}

Grehenson, G. 2016. UGM Canangkan Kemiri Sebagai Desa Mandiri Pangan. https://Ugm.Ac.Id/Id/Berita/18785-Ugm-Canangkan-Kemiri-Sebagai-Desa-MandiriPangan.

Kawuriaji, N. R., Nurtini, S., \& (Kustantinah), K. 2012. Distribusi Pendapatan Peternak Penggaduh Kambing Bligon di Gombang, Ponjong, Kabupaten Gunungkidul. Buletin Peternakan, 30(2), 97. https://doi.org/10.21059/buletinpeternak.v30i2.1200

Kustantinah, Indarto, E., Dono, N., Zuprizal, \& Zubaidah, S. 2016. Konsumsi dan Kecernaan Nutrien pada Kambing Kacang yang mendapat Pakan Tambahan Sumber Protein di Kelompok Wanita Sumber Rejeki, Wonolagi, Gunungkidul. Prociding Simposium Nasional Penelitian Dan Pengembangan Peternakan Tropik.

Kusumastuti, T. 2012. Kelayakan Usaha Ternak Kambing Menurut Sistem Pemeliharaan, Bangsa, dan Elevasi di Yogyakarta. Sains Peternakan, 10(2).

Murdjito, G., Budisatria, I. G. S., Panjono, Ngadiyono, N., \& Baliarti, E. 2011. Performances of Bligon goats kept byfarmers at Girisekar village, Panggang, Gunungkidul. Bulletin of Animal Science, 35(2), 86-90.

Murdjito, G., Budisatria, I. G. S., (Panjono), P., Ngadiyono, N., \& Baliarti, E. (2012). Kinerja Kambing Bligon Yang Dipelihara Peternak Di Desa Giri Sekar, Panggang, Gunungkidul. Buletin Peternakan, 35(2), 86. https://doi.org/10.21059/buletinpeternak.v35i2.595

Pamungkas, W. 2011. Teknologi Fermentasi, Alternatif Solusi Dalam Upaya Pemanfaatan Bahan Pakan Lokal. Media Akuakultur, 6(1), 43-48.

Sarmin, Widiyono, I., Astuti, P., \& Putro, P. P. (2017). Metabolic and Endocrine Responses to Feed Restriction andRefeeding in Kacang Goats. Pakistan Journal of Nutrition, 16(3), 101-108. https://doi.org/10.3923/pjn.2017.101.108

Suwignyo, B., Ahmad Baih, Z., Utomo, R., . S., \& Widiyono, I. 2017. Effects of Different Feed Restrictions on Kacang Goats. Pakistan Journal of Nutrition, 16(4), 236-241. https://doi.org/10.3923/pjn.2017.236.241

Villaquiran, M., Gipson, T., Merkel, R., Goetsch, A., \& Sahlu, T. 1977. Body Condition Scores in Goats. Langston University Agriculture Research \& Cooperative Extension Box 730 Langston, OK 73050 .

Widi, T., Baliarti, E., Ariyanti, F., Ngadiono, N., Budisatria, I., Panjono, \& Yulianto, M. 2016. Kinerja Anak Kambing Bligon Setelah Introduksi Pejantan Unggul di Kelompok Ternak Purwo Manunggal, Gunungkidul. Jurnal Sain Veteriner, 23(2), 251-258.

Widiyono, I., Sarmin, \& Putro, P. P. 2016. Influence of feed intake on blood chemistry parameters in Kacang goats. 140011. https://doi.org/10.1063/1.4958572 